Available online at website : http://journal.uinjkt.ac.id/index.php/dialektika

DIALEKTIKA: jurnal bahasa, sastra, dan pendidikan bahasa dan sastra Indonesia, 3(1), 2016, 87-99

\title{
PENGARUH PENGGUNAAN MEDIA GAMBAR BERSERI TERHADAP KEMAMPUAN MENULIS NARASI PESERTA DIDIK SEKOLAH MENENGAH PERTAMA (SMP)
}

\author{
Adi Permana, Hilda Hilaliyah, Ahmad Muzak \\ Universitas Indraprasta Jakarta, Indonesia \\ E-mail: adipermana84@yahoo.co.id
}

\begin{abstract}
The purpose of this study was to determine how the use of media images influence on the ability to write narrative series. This research is a quantitative experiment using a single experimental class and the control class as a comparison. Subjects were students of class VIII SMP IT Darus-Sholihin Sawangan as many as 32 students. Collecting data in this study using a test instrument board. Conclusions from this research that the use of media images affect the ability to write narrative series learners class VIII SMP IT Darus-Sholihin sawangan. In testing the hypothesis at the 5\% significance level obtained $t>t$ table (2.27> 1.75), so Ho refused and H1 accepted. So the hypothesis significantly verified and accepted. Thus concluded there are significant media use picture series on narrative writing skills of students. Average narrative writing skills of students who use the media image series (73.43) is higher than that using the conventional method (64.68)
\end{abstract}

Keywords: Media Image Serial; Narrative Writing; Influence

\begin{abstract}
Abstrak: Tujuan penelitian ini adalah untuk mengetahui pengaruh penggunaan media gambar seri terhadap kemampuan menulis narasi. Penelitian ini merupakan penelitian kuantitatif eksperimen dengan menggunakan satu kelas eksperimen dan satu kelas kontrol sebagai pembanding. Subjek penelitian adalah peserta didik kelas VIII SMP IT Darus-Sholihin Sawangan Depok sebanyak 32 siswa. Pengumpulan data dalam penelitian ini menggunakan instrument tes tulis. Simpulan dari hasil penelitian ini bahwa penggunaan media gambar seri mempengaruhi kemampuan menulis narasi peserta didik kelas VIII SMP IT Darus-Sholihin Sawangan Depok. Dalam pengujian hipotesis pada taraf signifikansi $5 \%$ diperoleh thitung > ttabel $(2,27>1,75)$, dengan demikian Ho ditolak dan H1 diterima. Sehingga hipótesis teruji kebenarannya dan secara signifikan diterima. Dengan demikian, dapat disimpulkan terdapat pengaruh penggunaan media gambar seri terhadap kemampuan menulis narasi siswa. Rata-rata kemampuan menulis narasi siswa yang menggunakan media gambar seri $(73,43)$ lebih tinggi dari pada yang menggunakan metode konvensional $(64,68)$.
\end{abstract}

Kata Kunci: media gambar berseri; menulis narasi; pengaruh

Permalink/DOI: http://dx.doi.org/10.15408/dialektika.v3i1.4184 


\section{Pendahuluan}

Dalam pelajaran Bahasa Indonesia, kita mengenal empat segi keterampilan berbahasa, yaitu keterampilan menyimak, keterampilan berbicara, keterampilan membaca, dan keterampilan menulis. Namun, dari empat keterampilan tersebut, keterampilan menulis merupakan keterampilan yang sulit untuk dipahami, khususnya bagi peserta didik madrasah ibtidaiyah. Hal itu dikarenakan keterampilan menulis merupakan keterampilan yang dikaitkan dengan seni atau kiat. Selain itu, terdapat juga faktor-faktor kendala yang dialami peserta didik, seperti kesulitan menentukan kalimat utama dan penjelas, jenuh belajar di dalam kelas, materi menulis yang monoton, kurangnya pengetahuan peserta didik dalam mengembangkan ide dan gagasan, serta terbatasnya kemampuan peserta didik dalam berimajinasi.

Berdasarkan hasil observasi dan wawancara dengan guru Bahasa Indonesia di beberapa madrasah ibtidaiyah, keterampilan menulis karangan telah diajarkan, tetapi belum mencapai ketuntasan karena masih menggunakan metode ceramah, sehingga peserta didik kurang tertarik dengan pembelajaran mengarang. Dengan demikian, hasil belajar mengarang peserta didik kurang maksimal. Hal ini dapat dilihat dari kesesuaian isi karangan dengan tema, pengembangan topik, tanda baca, dan diksi yang belum mendapat perhatian dari mereka.

Salah satu upaya yang dapat dilakukan oleh pendidik untuk membangkitkan gairah menulis dengan menggunakan media yang tepat dan menarik. Salah satu yang digunakan dengan media gambar berseri. Selain sebagai media pembelajaran, media gambar seri juga sangat membantu peserta didik dalam menulis karangan, khususnya karangan narasi. Hal itu terbukti pada saat peneliti melakukan observasi sederhana dengan menggunakan media gambar, kemampuan peserta didik dalam menulis karangan cukup baik dan sesuai dengan gambar yang telah diperlihatkan. Hal tersebut akan berdampak pada keberhasilan peserta didik dalam mengikuti pembelajaran, khususnya mengarang.

Media gambar merupakan salah satu media pembelajaran yang tepat untuk digunakan dalam menulis karangan narasi. Dengan menghadapkan peserta didik pada objek gambar, akan menstimulasi peserta didik untuk mengarang. Hal ini dilakukan agar aktivitas menulis menjadi kegiatan yang menarik. Selain itu, gambar juga akan sangat efektif digunakan untuk 
membantu memudahkan munculnya daya khayal atau imajinasi peserta didik dalam membuat karangan. Oleh karena itu, peneliti terdorong untuk melakukan penelitian yang berjudul "Pengaruh Media Gambar Seri terhadap Kemampuan Menulis Narasi Peserta Didik Sekolah Menengah Pertama (SMP)”.

\section{Tinjauan Pustaka}

\section{Hakikat Media Gambar Seri}

Menurut Nurgyantoro, gambar adalah simbol dari bentuk-bentuk benda asli yang dibuat di atas media (kertas, kanvas, dinding, dll), sedangkan gambar seri adalah bukan gambar tunggal, melainkan sebuah gambar (objek) yang merupakan satu kesatuan (berseri). ${ }^{1}$ Potensi gambar seri sebagai media pembelajaran menulis sangat tepat untuk digunakan. Selain itu, Sapari mengemukakan bahwa media gambar seri merupakan serangkaian gambar yang terdiri dari dari dua hingga enam gambar yang menceritakan suatu kesatuan cerita yang dapat dijadikan alur pemikiran peserta didik dalam mengarang. ${ }^{2}$

Setiap gambar berseri, dapat dijadikan paragraf. Di dalam tiap-tiap gambar seri terkandung cerita yang dapat diterjemahkan ke dalam tulisan dan dirangkai sesuai alur ceritanya, maka tulisan tersebut akan menjadi sebuah cerita. Gambar seri merupakan media pembelajaran yang terlihat diam tetapi sebenarnya bergerak dan berkata kepada yang peka dan penuh imajinasi. Jadi, dapat disimpulkan bahwa media gambar seri adalah alat bantu dalam proses belajar mengajar yang terdiri dari beberapa rangkaian gambar dan setiap satu buah gambar terdapat cerita yang dapat diterjemahkan ke dalam tulisan. Menurut Hasnindah ciri-ciri gambar seri, yaitu: a) Dapat menyampaikan pesan atau ide tertentu; b) Memberi kesan kuat dan menarik perhatian; c) Merangsang orang yang melihat untuk ingin mengungkapkan tentang objek-objek dalam gambar; d) Berani dan dinamis. e) Ilustrasi tidak banyak, tetapi menarik dan mudah dipahami.

Masih menurut Hasnindah, manfaat penggunaan media gambar seri adalah: a) Memperjelas penyajian pesan agar tidak terlalu bersifat verbalistis; b) Mengatasi keterbatasan ruang, waktu, dan daya indera seperti misalnya objek

\footnotetext{
${ }^{1}$ Burhan Nurgiyantoro, Teori Pengkajian Fiksi, (Yogyakarta: Gadjah Mada Universitas Press, 2002), h. 119.

${ }^{2}$ Hasnindah Abbas, "Meningkatkan Hasil Belajar Bahasa IndonesiaKeterampilan Menulis Materi Membuat Karangan Melalui Media Gambar Seri Sudirman III Makassar”. Skripsi, (Makassar: FIP UNM,2011), h. 8.

${ }^{3}$ Hasnindah Abbas, "Meningkatkan Hasil Belajar Bahasa IndonesiaKeterampilan Menulis Materi Membuat Karangan Melalui Media Gambar Seri Sudirman III Makassar”, Skripsi....., h. 9-11.
} 
benda yang terlalu besar, bisa digantikan dengan gambar, film bingkai, film, atau model; c) Fungsi lain dari media adalah dapat mengatasi sikap pasif peserta didik. Peserta didik menjadi aktif karena gairah belajar meningkat. d) Media juga memungkinkan terjadinya interaksi yang lebih langsung antara peserta didik dengan lingkungan dan memungkinkan peserta didik belajar mandiri menurut kemampuan dan minatnya.

Langkah-langkah penggunaan media gambar seri Menurut Hasnindah adalah sebagai berikut:

a. Menetapkan tujuan mengajar dengan menggunakan alat peraga, dalam hal ini merumuskan tujuan pembelajaran.

b. Persiapan guru, pada fase ini guru memilih dan menerapkan alat peraga mana yang akan digunakan untuk mencapai tujuan pembelajaran.

c. Persiapan kelas, Peserta didik satu kelas harus mempunyai persiapan sebelum mereka menerima pelajaran dengan menggunakan alat peraga.

d. Langkah penyajian pelajaran dan peragaan. Guru harus memilih keahlian dan keterampilan yang baik dalam menggunakan alat peraga. ${ }^{5}$

\section{Hakikat Kemampuan Menulis Narasi}

Kemampuan menulis bukanlah keterampilan yang diwariskan secara turun temurun. Kemampuan menulis merupakan hasil belajar dengan cara berlatih menulis. Untuk mencapai kemampuan ini, seseorang harus memahami benar tentang menulis. "Kemampuan menulis adalah kesanggupan atau kecakapan seseorang dalam mengungkapkan perasaan yang berkenaan dengan suatu pokok masalah secara jelas, lugas, dan tuntas dengan menggunakan bahasa tulis". Menurut Suriamiharja, dkk dalam Akhadiah, Keterampilan menulis adalah kemampuan seseorang dalam melukiskan lambang grafis yang dimengerti oleh penulis bahasa itu sendiri maupun orang lain yang mempunyai kesamaan pengertian terhadap simbol-simbol bahasa tersebut. Jadi, dapat disimpulkan bahwa kemampuan menulis adalah usaha atau kemampuan seseorang dalam menuliskan pemikirannya dengan jelas sehingga dapat dipahami oleh pembaca. ${ }^{7}$

\footnotetext{
${ }^{4}$ Hasnindah Abbas, "Meningkatkan Hasil Belajar Bahasa IndonesiaKeterampilan Menulis Materi Membuat Karangan Melalui Media Gambar Seri Sudirman III Makassar”, Skripsi....., h. 12-13.

${ }^{5}$ Hasnindah Abbas, "Meningkatkan Hasil Belajar Bahasa IndonesiaKeterampilan Menulis Materi Membuat Karangan Melalui Media Gambar Seri Sudirman III Makassar”, Skripsi....., h. 14-15.

${ }^{6}$ Aceng Hasani, Ihwal Menulis. (Jakarta: Untirta Press, 2005), h.2.

${ }^{7}$ Sabarti Akhadiah, dkk., Pembinaan Kemampuan Menulis Bahasa Indonesia (Jakarta: Erlangga, 1998), h.2.
} 


\section{Faktor-Faktor yang Memengaruhi Kemampuan Menulis}

Bagi seorang pemula, memulai menulis merupakan hal yang sulit. Namun, kalau menulis surat atau chatting dengan teman, suami, istri, atau saudara, mengapa bisa kita lakukan dengan lancar bahkan hasilnya bisa sampai berlembar-lembar?. Hal ini membuktikan bahwa semua orang memiliki bakat menulis, hanya saja perlu berlatih meningkatkan kemampuan menulis untuk berbagai kebutuhan. Kegiatan menulis seperti menciptakan suatu kebiasaan baru, artinya kita akan bisa menulis apabila kita sudah membiasakan diri untuk menulis. Namun, untuk membiasakan menulis bagi sebagian orang sama sulitnya dalam memulai membuat sebuah tulisan.

Banyak hambatan yang dialami oleh setiap orang. Selain itu, jenis hambatan yang dialami pun berbeda-beda. Menurut Wardhana dan Ardianto dalam Kuncoro, ada dua penyebab utama yang menjadi faktor penghambat kegiatan menulis yaitu:

\section{Faktor Internal}

Faktor internal merupakan faktor penghambat yang berasal dari dalam diri sendiri, seperti belum memiliki kebiasaan membaca buku, belum memiliki kemampuan berbahasa yang baik, dan belum adanya minat dan keinginan untuk menulis.

\section{Faktor Eksternal}

Faktor eksternal merupakan faktor penghambat yang berasal dari luar pribadi tiap individu, seperti sulit menemukan bahan acuan dan referensi untuk menulis, sulit mencari topik atau tema untuk bahan tulisan, dan kesulitan dalam menyusun kalimat baku. ${ }^{8}$

Jika kita melihat kedua jenis faktor tersebut, faktor penghambat yang paling sulit untuk ditangani adalah faktor yang berasal dari dalam diri sendiri (faktor internal). Hal ini disebabkan seseorang yang memiliki kebiasaan menulis tak lantas dengan waktu yang singkat ia akan menjadi terbiasa dan terampil menulis. Kemampuan ini tentunya akan dimulai dengan adanya minat dan keinginan seseorang untuk menulis. Jika hal yang paling mendasar itu tak dimiliki, maka untuk menjadikan kegiatan menulis sebagai suatu kebiasaan sangatlah sulit.

${ }^{8}$ Mudrajad Kuncoro, Metode Riset Untuk Bisnis \& Ekonomi, (Jakarta: Erlangga, 2009), h. 6-7. 
Menurut Leo Idra Ardiana, dkk. Menyatakan bahwa kegiatan menulis merupakan suatu keterampilan berbahasa. Dalam kegiatan menulis, untuk menghasilkan suatu tulisan yang baik mengharuskan setiap penulis memiliki tiga keterampilan dasar dalam menulis, yaitu:

3. Keterampilan Berbahasa

Keterampilan berbahasa ini merupakan keterampilan yang paling mendasar dan penting. Keterampilan berbahasa yang diperlukan seorang penulis mencakup keterampilan mengguna-

kan ejaan, pembentukan kata, pemilihan kata, dan penggunaan kalimat yang efektif.

4. Keterampilan Penyajian

Keterampilan penyajian merupakan keterampilan pembentukan dan pengembangan paragraf, keterampilan memerinci pokok bahasan menjadi subpokok bahasan, menyusun pokok nahasan dan subpokok bahasan ke dalam susunan yang sistematis. Hal ini memungkinkan tulisan dapat diikuti dan dipahami oleh pembaca dengan mudah.

5. Keterampilan Perwajahan

Keterampilan perwajahan merupakan keterampilan pengaturan tipografi dan pemanfaatan sarana tulis secara efektif dan efisien. Keterampilan ini diperlukan karena dapat mendukung kesempurnaan dan kerapian tulisan.

Narasi merupakan bentuk percakapan atau tulisan yang bertujuan menyampaikan atau menceritakan rangkaian peristiwa atau pengalaman manusia berdasarkan perkembangan dari waktu ke waktu. ${ }^{10}$ Narasi merupakan suatu bentuk wacana yang sasaran utamanya adalah tindak tanduk yang dijalin dan dirangkaikan menjadi sebuah peristiwa yang terjadi dalam satu kesatuan waktu.

Contoh Narasi

Tepat pada tanggal 21 Juni 2014 Capres Joko Widodo atau yang dikenal dengan sebutan Jokowi merayakan ulang tahun yang ke-53. Puluhan pedagang dan penarik becak yang biasa mangkal di daerah pasar Gede, Solo, Jawa Tengah,

\footnotetext{
${ }^{9}$ Leo Idra Ardiana, dkk., Pelatihan Terintegrasi Berbasis Kompetensi Guru Mata Pelajaran Bahasa Indonesia: Menyimak, (Jakarta: Direktur SUP, Dirjen Didasmen, Depdiknas,2002), h. 6.

${ }^{10}$ Atar Semi, Metode Penelitian Sastra. (Bandung: Angkasa, 2012), h.29.
} 
turut merayakan hari spesial mantan Walikota Solo itu dengan menggelar syukuran tumpengan. Selain itu, mereka juga berkumpul di depan pasar dengan membawa poster Joko Widodo dan Jusuf Kalla ( Jokowi - JK).

\section{Metode Penelitian}

\section{Desain Penelitian}

Dalam penelitian ini di gunakan metode eksperimen dengan design static group comparison, dimana dengan disain ini sudah ada kelompok lain sebagai standar eksternal. Desainnya adalah sebagai berikut :

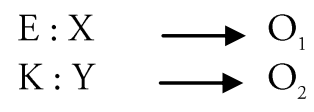

Keterangan :

$\mathrm{E}=\mathrm{X}$ kelompok eksperimen (Media gambar seri)

$\mathrm{K}=\mathrm{Y}$ kelompok kontrol (Media gambar non seri).

\section{Populasi dan Sampel}

Sugiyono dalam Ridwan menyatakan bahwa populasi adalah wilayah generalisasi yang terdiri dari objek atau suatu objek menjadi kuantitas atau karekteristik tertentu yang ditetapkan oleh peneliti untuk dipelajari kemudian ditarik kesimpulan. Populasi dalam penelitian ini adalah seluruh Peserta didik kelas VIII SMP IT Darus-Sholihin pada tahun ajaran 2014/2015 yang berjumlah 32 orang. ${ }^{11}$

Ariyanto dalam Ridwan mengatakan sampel adalah bagian dari populasi, sampel penelitian adalah sebagian populasi dari populasi yang diambil sebagai sumber data yang dapat mewakili seluruh populasi. Sampel dalam penelitian ini diambil dengan cara simple random sampling. Keseluruhan populasi diundi untuk menentukan dua kelas untuk dijadikan kelompok eksperimen dan kelompok kontrol. Adapun sampel yang diambil dalam penelitian ini sama dengan jumlah populasi. ${ }^{12}$

\section{Metode Pengumpulan Data}

Dalam penelitian kali ini peneliti menggunakan metode eksperimen, yakni suatu penelitian yang berusaha untuk mencari pengaruh variabel tertentu

\footnotetext{
${ }^{11}$ Ridwan, Belajar, Minat, Motivasi, Prestasi Belajar. http://www.artikel.Com/202/Belajar.minat, motivasi, prestasi belajar, h. 54 .

${ }^{12}$ Ridwan, Belajar Mudah penelitian untuk Guru-karyawan dan Peneliti. Pemula, (Bandung: Alfabeta, 2004), h. 5.
} 
terhadap variabel yang lain dalam kondisi yang terkontrol secara ketat. Adapun dalam penelitian ini peserta didik ditugaskan untuk mengarang dengan menggunakan media gambar seri dan tanpa menggunakan media gambar. Untuk tema, sudah ditentukan oleh peneliti yaitu "Kegiatan di Pagi Hari".

Metode pengumpulan data dalam penelitian ini adalah melalui tes. Tes yang dimaksud adalah tes kemampuan menulis narasi. Tes ini dilakukan sebanyak dua kali, yaitu sebelum perlakuan (pre-test) dan sesudah perlakuan (post-test). Pre-test berfungsi untuk mengukur kemampuan awal menulis narasi sebelum peserta didik mendapatkan perlakuan. Tes yang kedua disebut post-test yang berfungsi untuk mengetahui kemampuan akhir menulis narasi. Peserta didik pada kelompok eksperimen setelah mendapatkan perlakuan dengan menggunakan media gambar seri. Kedua tes ini juga diberikan pada kelompok kontrol yang berupa uraian. Hal ini dilakukan untuk mengetahui perbedaan kemampuan menulis narasi antara peserta didik yang menggunakan media gambar seri dan tanpa menggunakan gambar seri

\section{Teknik Analisis Data}

Teknik analisis data dalam penelitian ini meliputi uji persyaratan analisis data dan uji hipotesis penelitian. Uji persyaratan analisis data meliputi :

1. Uji normalitas dengan uji liliefors

2. Uji homogenitas dengan Fisher (F)

Sedangkan uji hipotesis penelitian menggunakan uji beda rata-rata (uji-t). Rumus yang digunakan untuk menghitung uji rata-rata adalah :

$$
t=\frac{\bar{X}_{x}-\bar{X}_{y}}{S_{g} \sqrt{\frac{1}{n_{x}}+\frac{1}{n_{y}}}} \quad S_{g}{ }^{2}=\frac{\left(n_{1}-1\right) S_{1}{ }^{2}+\left(n_{2}-1\right) S_{2}^{2}}{n_{1}+n_{2}-2}
$$

keterangan :

$\mathrm{X}_{1} \quad$ : mean kelompok eksperimen

$\mathrm{X}_{2} \quad$ : mean kelompok kontrol

n : banyaknya subjek

$S_{1} \quad$ : Simpangan baku pertama

$\mathrm{S}_{2} \quad$ : Simpangan baku kedua

$\mathrm{S}_{\mathrm{g}} \quad$ : Simpangan baku gabungan 
Kriteria uji: jika $t_{\text {hitung }}>t_{\text {tabel }}$ maka dikatakan eksperimen mempunyai pengaruh yang disignifikan. Jika $\mathrm{t}_{\text {hitung }}<\mathrm{t}_{\text {tabel }}$ maka dikatakan eksperimen tidak mempunyai pengaruh yang signifikan.

\section{Hipotesis Statistik}

$\begin{array}{ll}\mathrm{H}_{0} & : \mu_{1}=\mu_{2} \\ \mathrm{H}_{1} & : \mu_{1} \neq \mu_{2}\end{array}$

Yang berarti :

$\mathrm{H}_{0}$ : Terdapat pengaruh media gambar seri terhadap kemampuan menulis

$\mathrm{H}_{1}$ : Tidak terdapat pengaruh media gambar seri terhadap kemampuan menulis

\section{Pembahasan}

\section{Data Hasil Penelitian}

\begin{tabular}{ccc}
\hline Responden & \multicolumn{2}{c}{ Skor kelas } \\
\cline { 2 - 3 } & $\mathrm{E}$ & $\mathrm{K}$ \\
$\mathbf{1}$ & 60 & 50 \\
$\mathbf{2}$ & 60 & 50 \\
$\mathbf{3}$ & 65 & 55 \\
$\mathbf{4}$ & 65 & 60 \\
$\mathbf{5}$ & 70 & 60 \\
$\mathbf{6}$ & 70 & 60 \\
$\mathbf{7}$ & 70 & 60 \\
$\mathbf{8}$ & 70 & 60 \\
$\mathbf{9}$ & 75 & 65 \\
$\mathbf{1 0}$ & 75 & 65 \\
$\mathbf{1 1}$ & 75 & 65 \\
$\mathbf{1 2}$ & 80 & 70 \\
$\mathbf{1 3}$ & 80 & 70 \\
$\mathbf{1 4}$ & 85 & 80 \\
$\mathbf{1 5}$ & 85 & 80 \\
$\mathbf{1 6}$ & 90 & 85 \\
\hline
\end{tabular}

\section{Uji Normalitas Data}

1. Uji Normalitas Kelas Eksperimen

Dari hasil perhitungan diperoleh hasil $\mathrm{L}_{\text {hitung }}<\mathrm{L}_{\text {tabel }}$ atau $(0,152<0,220)$ maka terima $\mathrm{H} 0$ dan tolak $\mathrm{H} 1$ sehingga disimpulkan bahwa data berasal dari populasi berdistribusi normal. 
2. Uji Normalitas Kelas Kontrol

Dari hasil perhitungan diperoleh hasil $\mathrm{L}_{\text {hitung }}<\mathrm{L}_{\text {tabel }}$ atau $(0,177<0.220)$ maka terima $\mathrm{H} 0$ dan tolak $\mathrm{H} 1$ sehingga disimpulkan bahwa data berasal dari populasi berdistribusi normal

\section{Uji Homogenitas}

Uji Homogenitas dilakukan untuk menguji apakah terdapat kesamaan (homogen) atau ketidaksamaan varians populasi. Apabila ada kesamaan varians, maka dapat dikatakan bahwa populasi berasal dari varians yang homogen, atau sebaliknya.

Uji homogenitas menggunakan uji Fisher (Uji F), dimana :

$$
\begin{aligned}
& \mathrm{F}_{\text {hitung }}=\frac{\text { Varians terbesar }}{\text { Warians terkecil }} \\
& \mathrm{F}_{\text {hitung }}=\frac{104,89}{79,06} \\
& \mathrm{~F}_{\text {hitung }}=1,326
\end{aligned}
$$

Hasil analisis homogenitas dengan menggunakan taraf signifikansi $\alpha=$ 0,05 , diperoleh bahwa harga $F_{h}=1,326$ lebih kecil dari harga $F_{t}=7,815$. Dengan demikian dapat disimpulkan bahwa data penelitian tersebut memiliki variansi yang homogen.

\section{Pengujian Hipotesis Penelitian}

Uji hipotesis penelitian menggunakan uji beda rata-rata sebagai berikut :

$$
\begin{array}{r}
t=\frac{\bar{X}_{A}-\bar{X}_{B}}{s \sqrt{\left(\frac{1}{n_{A}}+\frac{1}{n_{B}}\right)}} \\
S_{g}{ }^{2}=\frac{\left(n_{1}-1\right) S_{1}{ }^{2}+\left(n_{2}-1\right) S_{2}{ }^{2}}{n_{1}+n_{2}-2}
\end{array}
$$

Dari distribusi frekuensi di atas didapat nilai

\begin{tabular}{llll}
\hline $\mathrm{X}_{1_{1}}$ & 73,43 & $\mathrm{X}_{2}$ & 64,68 \\
$\mathrm{~S}_{1}^{2}$ & 79,06 & $\mathrm{~S}_{2}^{2}$ & 104,89 \\
$\mathrm{~S}_{1}$ & 8,89 & $\mathrm{~S}_{2}$ & 10,24 \\
\hline
\end{tabular}

Sehingga diperoleh hasil sebagai berikut:

$$
S_{g}{ }^{2}=\frac{(16-1) * 79,06+(16-1) * 104,89}{16+16-2}
$$


$=91,97$

$t=\frac{73,43-64,68}{91,97 \sqrt{\left(\frac{1}{16}+\frac{1}{16}\right)}}$

$\mathrm{t}_{\text {hit }}=2,27$

$\mathrm{t}_{\mathrm{table}}=1,75$

Kriteria Uji :

Tolak $\mathrm{H}_{0}$ dan terima $\mathrm{H}_{1}$, jika $\mathrm{t}$ hitung $>\mathrm{t}$ tabel atau

Terima $\mathrm{H}_{0}$ dan tolak $\mathrm{H}_{1}$, jika thitung $<\mathrm{t}$ tabel.

Dalam pengujian hipotesis pada taraf signifikansi $5 \%$ diperoleh $t_{\text {hitung }}>$ $\mathrm{t}_{\text {tabel }},(2,27>1,75)$ maka Ho ditolak dan $\mathrm{H}_{1}$ diterima. Dengan demikian, hipotesis teruji kebenarannya dan secara signifikan diterima. Dengan demikian, dapat disimpulkan bahwa terdapat pengaruh penggunaan media gambar seri terhadap kemampuan menulis narasi siswa. Rata-rata kemampuan menulis narasi siswa yang menggunakan media gambar $(73,43)$ seri lebih tinggi dari pada yang menggunakan metode konvensional $(64,68)$

\section{Pembahasan Hasil Penelitian}

Berdasarkan hasil penelitian dan hasil pengujian hipotesis, maka terbukti bahwa terdapat pengaruh yang positif penggunaan media gambar seri terhadap kemampuan menulis narasi siswa. Dengan demikian, penelitian ini menghasilkan suatu kenyataan bahwa kemampuan menulis narasi siswa kelas VIII SMP IT Darus-Sholihin Sawangan Depok dipengaruhi oleh penggunaan media gambar seri artinya jika intensitas penggunaan media gambar seri pada penulisan karangan narasi baik, maka akan meningkatkan kemampuan siswa dalam menulis karangan narasi atau sebaliknya.

Berdasarkan hasil temuan dalam penelitian ini, maka dalam kapasitasnya sebagai seorang pendidik, guru mata pelajaran bahasa Indonesia harus mampu menciptakan media belajar yang baik bagi siswa agar dapat dilakukan pemilahan dan perlakuan yang tepat dalam kegiatan pembelajaran. Hasil penelitian menunjukkan bahwa secara umum penggunaan media gambar seri memberikan kontribusi perolehan menulis narasi peserta didik yang lebih baik. Dengan demikian, media gambar seri merupakan salah satu faktor yang tidak dapat diabaikan dalam pencapaian kemampuan menulis narasi peserta didik karena 
merupakan modal dasar dalam meningkatkan hasil belajar bahasa Indonesia di sekolah.

Dalam pengujian hipotesis pada taraf signifikansi $5 \%$ diperoleh $t_{\text {hitung }}>$ $\mathrm{t}_{\text {tabel }}(2,27>1,75)$, maka Ho ditolak dan $\mathrm{H}_{1}$ diterima. Dengan demikian hipotesis teruji kebenarannya dan secara signifikan diterima. Dengan demikian disimpulkan pula bahwa terdapat pengaruh penggunaan media gambar seri terhadap kemampuan menulis narasi atau rata-rata kemampuan menulis peserta didik yang menggunakan media gambar seri lebih tinggi daripada yang menggunakan media konvensional.

\section{Simpulan}

Dari hasil perhitungan dan analisis data diperoleh simpulan bahwa penggunaan media gambar seri mempengaruhi kemamapuan menulis narasi peserta didik SMP IT Darus-Sholihin Sawangan Depok. Dalam pengujian hipotesis pada taraf signifikansi $5 \%$ diperoleh $t_{\text {hitung }}>t_{\text {tabel }}$, maka Ho ditolak dan $\mathrm{H}_{1}$ diterima. Dengan demikian hipotesis teruji kebenarannya dan secara signifikan diterima. Dengan demikian dapat disimpulkan bahwa terdapat pengaruh penggunaan media gambar seri terhadap kemampuan menulis narasi siswa. Rata-rata kemampuan menulis narasi siswa yang menggunakan media gambar seri $(73,43)$ lebih tinggi daripada yang menggunakan metode konvensional $(64,68)$.

\section{Daftar Pustaka}

Abbas, Hasnindah. 2011. "Meningkatkan Hasil Belajar Bahasa IndonesiaKeterampilan Menulis Materi Membuat Karangan Melalui Media Gambar Seri Sudirman III Makassar”. Skripsi. Makassar: FIP UNM.

Akhadiah, Sabarti dkk. (1998). Pembinaan Kemampuan Menulis Bahasa. Indonesia. Jakarta: Erlangga.

Hasani, Aceng. 2005. Ihwal Menulis. Jakarta: Untirta Press.

Kuncoro, Mudrajad. 2009. Metode Riset Untuk Bisnis \& Ekonomi. Penerbit. Erlangga. Jakarta. 
Leo Idra Ardiana, dkk. 2002. Pelatihan Terintegrasi Berbasis Kompetensi Guru Mata Pelajaran Bahasa Indonesia: Menyimak. Jakarta: direktur SUP, Dirjen Didasmen, Depdiknas.

Nurgiyantoro, Burhan. 2002. Teori Pengkajian Fiksi. Yogyakarta: Gadjah Mada Universitas Press.

Ridwan. (2004). Belajar Mudah penelitian untuk Guru-karyawan dan Peneliti. Pemula. Bandung: Alfabeta

Ridwan. 2008. Belajar, Minat, Motivasi, Prestasi Belajar. http://www.artikel. Com/202/Belajar.minat, motivasi, prestasi belajar.

Rosidi, Ayip. 2008. Pembelajaran Sastra. Bandung: Angkasa.

Semi, Atar. 2012. Metode Penelitian Sastra. Bandung: Angkasa.

Syah, Muhibbin. 2003. Psikologi Belajar. Jakarta: PT Rajagrafido Persada.

Wellek, Rene dan Austin Warren, 1989. Teori kesusastraan. Jakarta: PT. Gramedia. 